\title{
ASSESSMENT OF EFFICIENCY OF AGRICULTURAL ENTERPRISE MANAGEMENT: METHODS AND TREND ANALYSIS
}

\author{
VALENTYNA YAKUBIV, ROMAN YAKUBIV, YUliIA MAKSYMIV, IRYNA HRYHORUK, \\ NAZARIY POPADYNETS, NATALIA IWASZCZUK
}

\begin{abstract}
The paper analyzes various scientific approaches to assessing the effectiveness of enterprise management. The advantages and disadvantages of using the four most common methods of assessing the effectiveness of enterprises are substantiated, such as 1) comprehensive assessment based on the methods of economic analysis; 2) analysis based on experimental estimates; 3 ) using the scoring method; 4) assessment based on testing. Given the fact that currently there is no single approach to assessing the effectiveness of enterprise management, including agricultural enterprises, the article proposes the author's method of assessing the effectiveness of management in agricultural enterprises. This methodology assumes that the effectiveness of management in agricultural enterprises is determined by integrating three indicators: economic efficiency of management, social efficiency of management, and organizational efficiency of management. The proposed methodology includes the gradual integration of partial 19 indicators in terms of economic, social, and organizational efficiency. Analysis of this phenomenon was conducted based on agricultural enterprises of the Ivano-Frankivsk region aimed at testing the developed methodology for assessing the effectiveness of management. The paper presents the research of the influence of the number of employees on the level of management efficiency in agricultural enterprises, the influence of enterprise size (by land area) on the level of management efficiency in agricultural enterprises, and the influence of average employment per 100 hectares of agricultural land on the level of agricultural management. The research was done using the grouping method. According to the results of the study, it was established that the developed methods for assessing the effectiveness of the management of agricultural enterprises can be used in practice.
\end{abstract}

Keywords: management, management efficiency, agricultural enterprises, economic efficiency, social efficiency, organizational efficiency.

JEL Classification: J5, Q12.

\section{INTRODUCTION}

The management of an agricultural enterprise is a combined economic and managerial category, which characterizes a set of organizational and managerial measures to influence employees.

Modern management theory is actively developing in the world, as it is based on changing working conditions of employees, the internal features of the development of individuals and managers. 
Given the wide popularity and branching of the modern management system of enterprises, the lack of a single scientifically sound approach to assessing the effectiveness of management remains an urgent problem. On the one hand, the existing pluralism of methodological approaches to assessing the effectiveness of management allows the researcher to choose the method that best suits or solves the problem. On the other hand, the variety of methods makes it impossible to conduct a comparative description of the effectiveness of management in different enterprises, in different periods, and so on. In turn, the lack of comparability hinders conducting an adequate, realistic assessment of the analyzed process.

\section{METHOD}

In domestic and foreign science, the most common methods of assessing the effectiveness of management in agricultural enterprises are:

1) comprehensive assessment based on the methods of economic analysis $[1 ; 2 ; 3]$;

2) analysis based on experimental estimates [4, 5];

3) using the scoring method $[6 ; 7 ; 8]$;

4) based on testing $[9,10]$.

Most scientists in the process of determining the effectiveness of personnel management use the methods of economic analysis. This, in our opinion, is because, first, this method allows you to get the most objective assessment, as it is based on financial and statistical data of the enterprise without the involvement of experts or other stakeholders. Secondly, this technique has the greatest potential for comparative analysis of individual enterprises or different reporting periods.

At the same time, an important disadvantage of applying only the methods of economic analysis is that such a complex concept as the effectiveness of personnel management is difficult to describe by several technical and economic indicators.

\section{RESUlTS AND Discussion}

With this in mind, we have developed our methodology for assessing the effectiveness of management in agricultural enterprises. This method of assessing the effectiveness of management of agricultural enterprises is based on the definition of 19 indicators (Tab. 1).

\begin{tabular}{|c|c|c|}
\hline $\begin{array}{c}\text { Levels of } \\
\text { management } \\
\text { efficiency }\end{array}$ & Indicators & Method of calculation \\
\hline \multirow{7}{*}{$\begin{array}{l}\text { Economic efficiency } \\
\text { of management }\end{array}$} & $\begin{array}{l}\text { Balance profit, thousand } \\
\text { UAH }\end{array}$ & Revenue from sales without production costs \\
\hline & $\begin{array}{l}\text { The level of return on } \\
\text { capital, } \%\end{array}$ & The ratio of profit to the value of fixed assets \\
\hline & $\begin{array}{l}\text { The level of product } \\
\text { profitability, } \%\end{array}$ & The ratio of profit to the cost of production \\
\hline & $\begin{array}{l}\text { Costs of } 1 \text { UAH products, } \\
\text { kop. / UAH }\end{array}$ & $\begin{array}{l}\text { The ratio of cost to the cost of commodity } \\
\text { products }\end{array}$ \\
\hline & $\begin{array}{l}\text { Volume of commodity } \\
\text { products, UAH }\end{array}$ & The cost of goods sold \\
\hline & Labor productivity, UAH & $\begin{array}{l}\text { The ratio of output to the total number of } \\
\text { workers employed in production }\end{array}$ \\
\hline & Number of employees, pers. & The average number of employees per year \\
\hline
\end{tabular}




\begin{tabular}{|c|c|c|}
\hline $\begin{array}{c}\text { Levels of } \\
\text { management } \\
\text { efficiency }\end{array}$ & Indicators & Method of calculation \\
\hline \multirow{6}{*}{$\begin{array}{l}\text { Organizational } \\
\text { efficiency of } \\
\text { management }\end{array}$} & $\begin{array}{l}\text { The ratio of productivity } \\
\text { growth and wages, } \%\end{array}$ & $\begin{array}{l}\text { The ratio of productivity growth to average } \\
\text { wage growth }\end{array}$ \\
\hline & $\begin{array}{l}\text { Frequency of occupational } \\
\text { injuries, } \%\end{array}$ & $\begin{array}{l}\text { The ratio of the number of cases of } \\
\text { occupational injuries to the total number of } \\
\text { staff }\end{array}$ \\
\hline & Product quality, points or $\%$ & $\begin{array}{l}\text { The ratio of proportion of the lack to the } \\
\text { volume of production }\end{array}$ \\
\hline & $\begin{array}{l}\text { Level of labor discipline, } \\
\text { violation/people or points }\end{array}$ & $\begin{array}{l}\text { The ratio of the number of cases of violation of } \\
\text { labor and executive discipline to the total } \\
\text { number of staff }\end{array}$ \\
\hline & Staff stability coefficient & $\begin{array}{l}\text { The ratio of the number of employees with } \\
\text { experience in the organization more than one } \\
\text { year (for a certain period) to the average } \\
\text { number of employees for the relevant period }\end{array}$ \\
\hline & Coefficient of discipline & $\begin{array}{l}\text { The ratio of absenteeism to the total number of } \\
\text { man-hours for the relevant period }\end{array}$ \\
\hline \multirow{5}{*}{$\begin{array}{l}\text { Social efficiency of } \\
\text { management }\end{array}$} & Remuneration fund, UAH & General fund of basic and additional wages \\
\hline & $\begin{array}{l}\text { Average salary per } 1 \text { worker, } \\
\text { UAH / month }\end{array}$ & $\begin{array}{l}\text { The ratio of the general wage fund to the total } \\
\text { number of staff }\end{array}$ \\
\hline & Staff turnover rate, coefficient & $\begin{array}{l}\text { The ratio of the number of employees who } \\
\text { resigned from the organization during a certain } \\
\text { period (minus inevitably dismissed) to the } \\
\text { average number of employees for the relevant } \\
\text { period }\end{array}$ \\
\hline & $\begin{array}{l}\text { Uniformity of staff loading, } \\
\text { points }\end{array}$ & $\begin{array}{l}\text { The ratio of the number of working days } \\
\text { (employment) of employees to the total } \\
\text { number of working days in the period }\end{array}$ \\
\hline & $\begin{array}{l}\text { Socio-psychological climate } \\
\text { of the team, points }\end{array}$ & $\begin{array}{l}\text { Established on the basis of specific sociological } \\
\text { and psychological research }\end{array}$ \\
\hline
\end{tabular}

Tab. 1. The system of indicators for assessing the effectiveness of management in agricultural enterprises. Source: developed by the authors.

All indicators are classified in three groups or levels of efficiency of personnel management: economic, organizational and social.

The first level of management efficiency (economic) is characterized by the main performance indicators of agricultural enterprises, which to some extent indicate the effectiveness or inefficiency of management.

The second level of management efficiency (organizational) is described by a set of indicators reflecting the working conditions of employees in the enterprise, the level of discipline and other parameters of management efficiency of labor organization and production.

The third level of management efficiency (social) includes a number of indicators characterizing the effectiveness of management in terms of effect for employees. This group of indicators is important because it shows the degree of employee satisfaction with the created working conditions, the level of wages and so on. It is obvious that the presence of a social effect will indicate changes in the productivity of employees, and hence in the efficiency of the enterprise as a whole.

Indicators (listed in table 1) in terms of three levels of management efficiency are closely interrelated, as they interdependent changes. Economic and social efficiency largely depends on the 
organized efficiency of personnel management.

In order to test the developed methods in practice, an assessment of the effectiveness of management of agricultural enterprises in Ivano-Frankivsk region was done. The object of the study was 103 enterprises of the region, reported in the form № 50-ag. The analysis was conducted for the period 2015-2018.

According to the results of the calculations, it was determined that the highest level of management efficiency was 0.27 in the enterprise of Rozhnyativ district, the highest indicator was in Rohatyn district and amounted to 51.26 .

To conduct further research and identify trends and factors affecting the effectiveness of personnel management of agricultural enterprises, we divided the results in three groups (Tab. 2).

\begin{tabular}{|c|c|c|l|}
\hline Groups & $\begin{array}{c}\text { Number of } \\
\text { enterprises in the } \\
\text { group }\end{array}$ & $\begin{array}{c}\text { The average value } \\
\text { of the level of } \\
\text { personnel } \\
\text { management } \\
\text { efficiency }\end{array}$ & \multicolumn{1}{c|}{$\begin{array}{c}\text { Number of enterprises by districts of the } \\
\text { region }\end{array}$} \\
\hline $\begin{array}{c}\text { I group - up to } \\
17.27\end{array}$ & 58 & 9.34 & $\begin{array}{l}\text { Ivano-Frankivsk - 3; Bohorodchany - 4; } \\
\text { Halytsky - 3; Horodenkivskyi - 4; Dolynsky - } \\
\text { 2; Kolomyia - 9; Rohatynsky - 7; } \\
\text { Rozhnyativsky - 2; Sniatynsky - 10; } \\
\text { Tlumatsky - 6; Tysmenytskyi - 8 }\end{array}$ \\
\hline $\begin{array}{c}\text { II group- } \\
17,28-34.28\end{array}$ & 37 & 24.27 & $\begin{array}{l}\text { Ivano-Frankivsk - 1; Halytsky - 2; } \\
\text { Horodenkivskyi - 7; Kolomyia - 4; } \\
\text { Nadvirnyansky - 1; Rohatynsky - 7; } \\
\text { Sniatynsky - 6; } \\
\text { Tlumatsky - 4; Tysmenytskyi - 5 }\end{array}$ \\
\hline $\begin{array}{c}\text { III group- } \\
34.29-\text { and } \\
\text { more }\end{array}$ & 8 & $\begin{array}{l}\text { Horodenkivskyi - 2; Kalush - 1; } \\
\text { Kolomyia - 1; Rohatynsky - 1; } \\
\text { Sniatynsky - 1; } \\
\text { Tlumatsky - 1; } \\
\text { Tysmenytsky - 1. }\end{array}$ \\
\hline
\end{tabular}

Tab. 2. Grouping of agricultural enterprises of Ivano-Frankivsk region at the level of management efficiency. Source: calculated on the basis of [11].

Table 2 summarizes a number of conclusions:

1) the most numerous group in terms of management efficiency is group I, where the integrated analyzed indicator is up to 9.34 . The number of enterprises included in this group is 58 units or $56 \%$ of all agricultural enterprises in the region. This group includes enterprises of all levels of Ivano-Frankivsk region. Undoubtedly, this indicates negative trends in the organization of management activities of agricultural enterprises;

2) the second group of enterprises with the level of management efficiency according to the integrated indicator Emp from 17.28 to 34.28 includes 37 enterprises or $36 \%$, i.e. about a third of all enterprises. The average value of the analyzed indicator Emp in the group is only 24.27.

3) the third group of enterprises with the level of management efficiency includes only 8 enterprises, which is only $7.8 \%$ of the total number of agricultural enterprises in Ivano-Frankivsk region. The average value of the analyzed indicator is 44.49 , which is 4.8 times higher than the indicator for group I and 1.8 times higher than the average for group II. In the territorial aspect, the analysis shows that such enterprises are presented, as a rule, by one unit in certain calculations. Additional calculations and observations show that this group includes powerful agricultural enterprises of the Landfarm agroholding group and other enterprises with foreign investment. For the most part, these agricultural formations specialize in the animal sector. 
The next stage of the study is to establish the relationship of the analyzed integrated indicator with the number of labor of the enterprise 1 (Tab. 3).

\begin{tabular}{|c|c|c|c|}
\hline Groups & $\begin{array}{c}\text { Number of } \\
\text { enterprises in the } \\
\text { group }\end{array}$ & $\begin{array}{c}\text { The average value of } \\
\text { the level of } \\
\text { management efficiency }\end{array}$ & $\begin{array}{c}\text { The average number } \\
\text { of employees per 1 } \\
\text { enterprise, pers. }\end{array}$ \\
\hline I group - up to 17.27 & 58 & 9.34 & 26 \\
\hline II group - $17.28-34.28$ & 37 & 24.27 & 34 \\
\hline III group - $34.29-$ and more & 8 & 44.49 & 86 \\
\hline
\end{tabular}

Tab. 3. Analysis of the impact of the number of employees on the level of efficiency of their management. Source: calculated on the basis of [11].

From the data of table 3 and some other performed calculations the conclusions are generalized. There is a direct relationship between the level of efficiency of personnel management and the average number of employees in agricultural enterprises. Thus, the highest level of efficiency of personnel management is observed in those enterprises where there are more employees. Thus, the first group according to the indictor Emp includes enterprises with an average number of employees of 26 people, the second group includes agricultural formations, where the average number of employees is 34 people, the third group includes enterprises with an average number of employees of 86 people, which is 3.5 times more than in group I enterprises and 2.5 times more than in group II enterprises.

This is due to the fact that in large enterprises, including enterprises with foreign investment, there is an extensive management system, including personnel management, and new techniques are used in the management of the enterprise and personnel.

Thus, the data in Table 3 show that there is a direct close relationship between the number of employees in agricultural enterprises and the level of efficiency of their management. As the number of employees increases, the effectiveness of the management process grows.

To deepen this study, an analysis was conducted to establish the relationship between the size of enterprises (by land area) and the level of efficiency of personnel management (Tab. 4).

Based on the data in table 4, we can summarize a number of conclusions. Thus, there is a direct relationship between the size of agricultural enterprises (by land area) and the level of efficiency of personnel management. If in group I with the lowest level of management efficiency $($ Emp $=9.34)$ the average farm size is 1041.9 ha, then in group II, where Emp is 24.27, i.e. 2.6 times more, the average size of agricultural formations is 1255.8 hectares, which is 213.9 hectares or 1.2 times more than in group I.

\begin{tabular}{|c|c|c|c|}
\hline Groups & $\begin{array}{c}\text { Number of } \\
\text { enterprises in } \\
\text { the group }\end{array}$ & $\begin{array}{c}\text { The average value of the } \\
\text { level of management } \\
\text { efficiency }\end{array}$ & $\begin{array}{c}\text { The arable land of } \mathbf{1} \\
\text { enterprise, ha }\end{array}$ \\
\hline I group - up to 17.27 & 58 & 9.34 & 1041.9 \\
\hline II group - $17.28-34.28$ & 37 & 24.27 & 1255.8 \\
\hline III group - 34.29 - and more & 8 & 44.49 & 5376.7 \\
\hline
\end{tabular}

Tab. 4. The influence of the size of enterprises (by land area) on the level of efficiency of enterprise management. Source: calculated on the basis of [11].

In the third group of enterprises indicator Emp is 44.49, which is 1.8 times higher than in the second group and 4.8 times higher than in the first group. Accordingly, the area of agricultural land per 1 enterprise in group III is 4.3 times larger than in group II and 5.2 times larger than in group I.

From the calculations it follows that in group III the average size of enterprises and other 
performance indicators of enterprises are much higher than in other enterprises of the region.

The next step in the study of causal relationships and dependencies is to analyze the impact of staffing per 100 hectares of land on the level of efficiency of its management (Tab. 5).

\begin{tabular}{|c|c|c|c|}
\hline Groups & $\begin{array}{c}\text { Number of } \\
\text { enterprises in } \\
\text { the group }\end{array}$ & $\begin{array}{c}\text { The average value of the } \\
\text { level of management } \\
\text { efficiency }\end{array}$ & $\begin{array}{c}\text { The average number of } \\
\text { employees per 100 } \\
\text { hectares of land, pers. }\end{array}$ \\
\hline I group - up to 17.27 & 58 & 9.34 & 27 \\
\hline II group - $17.28-34.28$ & 37 & 24.27 & 29 \\
\hline III group - $34.29-$ and more & 8 & 44.49 & 19 \\
\hline
\end{tabular}

Tab. 5. Analysis of the impact of land supply of enterprises by staff on the level of efficiency of its enterprise management. Source: calculated on the basis of [11].

From the data of table 5 and the data of other calculations we have a number of conclusions:

1) between the analyzed indicators there is no direct relationship in trends;

2) in the enterprises of groups I and II, where Emp is 9.34 and 24.27, respectively, the average number of employees per 100 hectares of land was 27 and 29, respectively, i.e. almost the same. In the third group of enterprises - where the Emp indicator is much higher - 44.49, the average number of employees per 100 hectares of land is only 19;

3) additional analysis shows that the reasons for this are that a small number of enterprises of group III - 8 units is characterized by a high level of technical and technological equipment, organization of production and labor, which allows to use less manual labor, obtaining higher performance. In addition, most companies in this group specialize in animal husbandry, including PJSC "Avargard" (Tysmenytsia district), LLC "Rosan-Agro" (Rohatyn district), LLC "Stern-Agro" (Tlumach district), LLC "Danosha" (Kalush district). These enterprises usually use the area of agricultural land to obtain the necessary fodder base.

The results of research (Tab. 6) showed that the level of management efficiency is directly dependent on the amount of resources involved in the production process. The larger the company, the higher the concentration of production, the more rationally organized personnel management.

\begin{tabular}{|c|c|c|c|}
\hline \multirow{2}{*}{ Indicator } & \multicolumn{3}{|c|}{$\begin{array}{c}\text { Group of enterprises by the level of efficiency } \\
\text { of personnel management }\end{array}$} \\
\cline { 2 - 4 } & I. Emp to 17.27 & $\begin{array}{c}\text { II. Emp 17.28 - } \\
34.28\end{array}$ & $\begin{array}{c}\text { III. Emp 34.29 } \\
\text { and more }\end{array}$ \\
\hline Number of enterprises in the group & 58 & 37 & 8 \\
\hline $\begin{array}{c}\text { The average value of the level of efficiency } \\
\text { of personnel management }\end{array}$ & 9.34 & 24.27 & 44.49 \\
\hline $\begin{array}{c}\text { The average number of agricultural } \\
\text { employees per enterprise, persons }\end{array}$ & 26 & 34 & 86 \\
\hline Area of agricultural land per enterprise, ha & 1042 & 1256 & 5377 \\
\hline $\begin{array}{c}\text { The average number of employees per 100 } \\
\text { hectares of agricultural land lands, persons }\end{array}$ & 2.5 & 2.7 & 1.6 \\
\hline
\end{tabular}

Tab. 6. Dependence on the effectiveness of agricultural management enterprises of Ivano-Frankivsk region from certain factors, on average for 2015-2018. Source: calculated on the basis of [11]. 
Thus, based on the developed methodology for assessing the effectiveness of management of agricultural enterprises a comprehensive analysis of agricultural formations of Ivano-Frankivsk region was conducted. The main causal relationships and factors that affect the level of effectiveness of the management process were identified.

\section{CONCLUSIONS}

Based on the development of various scientific approaches to assessing the effectiveness of management of agricultural enterprises, we have developed our own methodology for assessing the effectiveness of management of agricultural enterprises, based on an integrated assessment of three components of enterprise management: economic efficiency, social management and organizational management. Approbation of this method was based on the analysis of agricultural enterprises of Ivano-Frankivsk for the period 2015-2018. In the process of assessing the effectiveness of management of agricultural enterprises, the main factors influencing this process by using the grouping method were investigated. The results of the approbation showed that the developed methodology for assessing the effectiveness of management of agricultural enterprises can be used in practice.

\section{REFERENCES}

[1] Zavadsky J.S. Management: in 2 volumes. Kyiv, 2003. (in Ukrainian)

[2] Kuzmin O.Ye., Melnyk O.G. Fundamentals of Management: A Textbook. Kyiv, 2007. (in Ukrainian)

[3] Yakubiv V.M., Gorogotska N.I., Yakubiv R.D. Management model of agricultural enterprises development through implementation of diversification processes. Current Issues in Economics, 8 (2015), $58-65$.

[4] Yakubiv V., Boryshkevych I. Strategic analysis of the development of renewable energetics in the world and in Ukraine. Journal of Vasyl Stefanyk Precarpathian National University, 5 (3-4) (2018), 33-43. doi: 10.15330/jpnu.5.3-4.33-43

[5] Yakubiv V., Polujk M. Innovative methodologies for estimating the personnel of agricultural enterprises in Ukraine. Scientific Papers. Series "Management, Economic Engineering in Agriculture and Rural Development", 19 (1) (2019). Available at: http://managementjournal.usamv.ro/pdf/vol.19_1 /volume_19_1_2019.pdf

[6] Yakubiv V. Accounting and analytical methods of diagnostics improvement for enterprises' organizational development. Economic Annals-XXI, 3-4 (1) (2015), 68-71.

[7] Osovskaya G.V., Osovskaya O.A. Fundamentals of Management: A Textbook. Kyiv, 2006. (in Ukrainian)

[8] Ian Mann. Reviews: Bedtime stories for managers. Available at: https://www.fin24.com/Opinion/ianmann-reviews-bedtime-stories-for-managers-20191014

[9] Lukianykhin V.A. Staff Management: A Training Manual. Kyiv, 2004. (in Ukrainian)

[10] Boryshkevych I. Formulation of a typical development strategy for agricultural enterprises (by the method of hoshin kanri). Journal of Vasyl Stefanyk Precarpathian National University, 6 (3-4) (2019), 15-21.

[11] Statistical Yearbook of Ivano-Frankivsk region 2018: Statistical collection. Main Department of Statistics in Ivano-Frankivsk region, Ivano-Frankivsk, 2019. (in Ukrainian) 
Address: Valentyna Yakubiv, Roman Yakubiv, Yuliia Maksymiv, Iryna Hryhoruk, Vasyl Stefanyk Precarpathian National University, 57 Shevchenko St., Ivano-Frankivsk, 76018 Ukraine;

Nazariy Popadynets, M. I. Dolishniy Institute of Regional Research of NAS of Ukraine, 4 Kozeletska St., Lviv, 79026 Ukraine;

Natalia Iwaszczuk, AGH University of Science and Technology, 30 al. Mickiewicza, Krakow, 30059 Poland.

E-mail: yakubiv.valentyna@gmail.com, roman.yakubiv@gmail.com, yuliia.maksymiv@pnu.edu.ua, iryna.hryhoryk@pnu.edu.ua, popadynets.n@gmail.com, natalia.iwaszczuk@gmail.com

Received: July 6, 2020; revised: August 20, 2020.

Якубів Валентина, Якубів Роман, Максимів Юлія, Григорук Ірина, Попадинець Назарій, Іващук Наталія. Оцінка ефективності управління сільськогосподарськими підприємствами: методика та аналіз тенденцій. Журнал Прикарпатського університету імені Василя Стефаника, 7 (3) (2020), 19-26.

У статті проаналізовано різні наукові підходи до здійснення оцінки ефективності управління підприємствами. Обгрунтовано переваги і недоліки використання чотирьох найпоширеніших методів оцінки ефективності діяльності підприємств: 1) комплексна оцінка на методах економічного аналізу; 2) аналіз на основі експериментних оцінок; 3) за допомогою бального методу; 4) на основі тестування. Враховуючи те, що на даний час відсутній єдиний підхід до оцінки ефективності управління підприємствами, і в т.ч. сільськогосподарськими підприємствами, у статті запропоновано авторську методику оцінки ефективності менеджменту на сільськогосподарських підприємств. Дана методика передбачає, що ефективність управління на сільськогосподарських підприємствах визначається шляхом інтегруванням трьох показників: економічної ефективності управління, соціальної ефективності управління та організаційної ефективності управління. Запропонована методика передбачає поетапне інтегрування часткових 19 показників в розрізі економічної, соціальної та організаційної ефективності діяльності. 3 метою апробації розробленої методики оцінки ефективності управління проведено аналіз даного явища на базі сільськогосподарських підприємств Івано-Франківської області. На основі використання методу групування досліджено вплив чисельності працівників на рівень ефективності менеджменту на сільськогосподарських підприємствах, вплив розміру підприємства (за площами земель) на рівень ефективності менеджменту на сільськогосподарських підприемствах та вплив середнього рівня забезпеченості працівниками на 100 га сільськогосподарських угідь на рівень ефективності управління агроформуваннями. За результатами дослідження встановлено, що розроблена нами методика оцінки ефективності управління сільськогосподарськими підприємствами може використовуватись на практиці.

Кдючові слова: управління, ефективність управління, сільськогосподарські підприємства, економічна ефективність, соціальна ефективність, організаційна ефективність. 